КОРНІЛОВА О. В., аспірантка кафедри трудового права та права соціального забезпечення (Національний університет «Одеська юридична академія»)

УДК 349.3: (364.4:616-071)

DOI https://doi.org/10.32842/2078-3736-2019-6-1-27

\title{
ПОНЯТТЯ ТА ОСНОВНІ ОЗНАКИ ТРЕТИННОЇ (ВИСОКОСПЕЦАЛІЗОВАНОЇ) МЕДИЧНОЇ ДОПОМОГИ
}

Стаття присвячена дослідженню правового регулювання третинної (висококваліфікованої) медичної допомоги за законодавством України.

У статті детально досліджено положення ст. 35-3 Основ законодавства України про охорону здоров'я про поняття третинної (висококваліфікованої) медичної допомоги, виокремлено їі основні ознаки.

Проаналізовано накази Міністерства охорони здоров'я України у сфері регулювання відносин із надання третинної (висококваліфікованої) медичної допомоги. Підкреслено необхідність уточнення змісту статті 35-3 щодо поняття третинної (висококваліфікованої) медичної допомоги з урахуванням її основних ознак.

Зазначено про невідповідність норм наказу Міністерства охорони здоров'я положенням ст. 35-3 Основ законодавства України про охорону здоров'я щодо порядку здійснення суб'єктами надання третинної (висококваліфікованої) медичної допомоги.

Визначено основні ознаки третинної (висококваліфікованої) медичної допомоги, з урахуванням яких сформульоване визначення поняття цього виду медичної допомоги, яке слід закріпити у ст. 35-3 Основ законодавства України про охорону здоров'я.

Зроблено висновок щодо доцільності законодавчого визначення чіткого та вичерпного переліку екстрених випадків надання третинної (висококваліфікованої) медичної допомоги.

Сформульовано теоретично обгрунтовані пропозиції про вдосконалення чинного законодавства України у сфері надання третинної (висококваліфікованої) медичної допомоги.

Ключові слова: охорона здоров'я, медична допомога, третинна (високоспеціалізована) медична допомога, поняття третинної (високоспеціалізованої) медичної допомоги, ознаки третинної (високоспеціалізованої) медичної допомоги.

The article is devoted to the study of legal regulation of tertiary (highly qualified) medical care under the legislation of Ukraine.

The article investigates in detail the provisions of Art. 35-3 Basics of the legislation of Ukraine on health care about the concept of tertiary (highly qualified) medical care, its main features are highlighted.

The orders of the Ministry of Health of Ukraine in the sphere of regulation of relations on providing tertiary (highly qualified) medical care are analyzed. The need to clarify the content of Article 35-3 regarding the concept of tertiary (highly qualified) medical care was emphasized, taking into account its basic features.

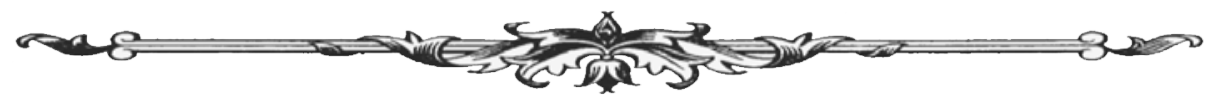


It is stated that the Ministry of Health has failed to comply with the provisions of Art. 35-3 Basics of the legislation of Ukraine on health care concerning the procedure of implementation by the subjects of provision of tertiary (highly qualified) medical care.

The main features of tertiary (highly qualified) medical care have been determined, taking into account the definition of the concept of this type of medical care, which should be fixed in Art. 35-3 Basics of the Ukrainian legislation on health care.

The conclusion is made about the expediency of legislative definition of a clear and exhaustive list of emergency cases of providing tertiary (highly qualified) medical care.

Theoretically substantiated proposals for improving the current legislation of Ukraine in the field of providing tertiary (highly qualified) medical care have been formulated.

Key words: health care, medical care, tertiary (highly specialized) medical care, the concept of tertiary (highly specialized) medical care, signs of tertiary (highly specialized) medical care.

Вступ. Реформування у сфері медицини передбачає створення нової та більш ефективної системи медичного обслуговування населення та надання якісних медичних послуг, насамперед для реалізації конституційного права кожного на охорону здоров'я, медичну допомогу та медичне страхування (ст. 49 Конституція України).

Проблема надання якісної та висококваліфікованої медичної допомоги населенню $\epsilon$ найбільш актуальною на даному етапі розвитку держави, адже здоров'я $\epsilon$ визначальною характеристикою як окремої людини, так і нації загалом.

Однією з основних функцій держави, яка проголошена у ст. 1 Конституції України соціальною державою, є забезпечення охорони здоров'я населення, надання ефективного та доступного для всіх громадян медичного обслуговування, у тому числі надання третинної (висококваліфікованої) медичної допомоги.

Аналіз основних досліджень та публікацій. Проблеми правового регулювання третинної (висококваліфікованої) медичної допомоги є малодослідженими у науці права соціального забезпечення. Окремі питання у сфері третинної (висококваліфікованої) медичної допомоги потребують детального та змістовного обгрунтування, зокрема такі, як визначення поняття та основних ознак третинної (висококваліфікованої) медичної допомоги.

Така необхідність зумовлюється змінами в національному законодавстві і процесами, які відбуваються під керівництвом Міністерства охорони здоров'я України у сфері реформування медичної допомоги, в тому числі й третинної (висококваліфікованої) медичної допомоги.

Постановка завдання. Метою статті є визначення поняття та основних ознак третинної (висококваліфікованої) медичної допомоги.

Результати дослідження. У січні 2018 року було започатковане реформування у сфері медицини з метою покращення умов надання медичних послуг та якості медичної допомоги, в тому числі третинної (висококваліфікованої) медичної допомоги. Указ Президента України «Про Стратегію сталого розвитку «Україна - 2020» від 12 січня 2015 року № 5/201 [5] основною метою у сфері реформування охорони здоров'я визначає кардинальне, системне реформування, спрямоване на створення системи, орієнтованої на пацієнта, здатної забезпечити медичне обслуговування для всіх громадян України на рівні розвинутих європейських держав. Головними напрямами реформ мають стати підвищення особистої відповідальності громадян за власне здоров'я, забезпечення для них вільного вибору постачальників медичних послуг належної якості, надання для цього адресної допомоги найбільш соціально незахищеним верствам населення, створення бізнес-дружньої обстановки на ринку охорони здоров'я.

У вітчизняній спеціальній літературі не визначено поняття третинної (висококваліфікованої) медичної допомоги. Це поняття сформульоване на законодавчому рівні в Основах законодавства України про охорону здоров'я від 19 листопада 1992 року [1]. Відповідно до

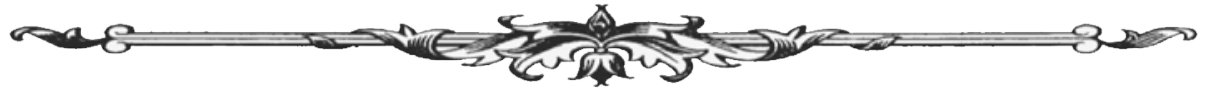


пункту 1 статті 35-3 Основ третинна (високоспеціалізована) медична допомога - медична допомога, що надається в амбулаторних або стаціонарних умовах у плановому порядку або в екстрених випадках і передбачає надання консультації, проведення діагностики, лікування хвороб, травм, отруєнь, патологічних станів, ведення фізіологічних станів (під час вагітності та пологів) із застосуванням високотехнологічного обладнання та/або високоспеціалізованих медичних процедур високої складності; направлення пацієнта відповідно до медичних показань для надання вторинної (спеціалізованої) медичної допомоги або третинної (високоспеціалізованої) медичної допомоги з іншої спеціалізації.

Аналіз зазначеного поняття свідчить про його неповноту, оскільки в ньому не враховуються й інші основні ознаки третинної (висококваліфікованої) медичної допомоги, а саме характер надання - амбулаторний або стаціонарний.

Згідно з пунктом 1.4 Порядку організації медичного обслуговування та направлення пацієнтів до закладів охорони здоров'я, що надають вторинну (спеціалізовану) та третинну (високоспеціалізовану) медичну допомогу, затвердженого наказом Міністерства охорони здоров’я України від 05 жовтня 2011 року № 646 [3], третинна медична допомога надається в стаціонарних та амбулаторних умовах багатопрофільними обласними лікарнями (клінічна лікарня), багатопрофільними обласними дитячими лікарнями (клінічними лікарнями), високоспеціалізованими медичними центрами (за напрямами).

Варто зауважити, що зазначене поняття також не відповідає положенням пункту 2 статті 35-3 Основ законодавства про охорону здоров'я, відповідно до якого надання третинної (високоспеціалізованої) медичної допомоги здійснюється високоспеціалізованими багатопрофільними або однопрофільними закладами охорони здоров'я.

Наказом Міністерства охорони здоров’я України від 28 жовтня 2002 року № 385 [2] затверджені переліки закладів охорони здоров'я, лікарських, провізорських посад, посад молодших спеціалістів з фармацевтичною освітою, посад професіоналів у галузі охорони здоров'я та посад фахівців у галузі охорони здоров'я з у закладах охорони здоров'я», у тому числі й медичних установ, які належать до багатопрофільних та однопрофільних лікарень.

Наступною ознакою, яку варто виокремити у понятті третинної (висококваліфікованої) медичної допомоги, $є$ порядок iї надання в планових або в екстрених випадках.

Плановий порядок щодо надання третинної (висококваліфікованої) медичної допомоги затверджений наказом Міністерства охорони здоров'я України, Національної академії медичних наук України «Про затвердження нормативно-правових актів МОЗ України та НАМН України щодо реалізації постанови Кабінету Міністрів України» від 14 червня 2017 року № 425 «Деякі питання реалізації пілотного проекту щодо зміни механізму фінансування надання медичної допомоги в окремих науково-дослідних установах Національної академії медичних наук» від 28 червня 2017 року № 967/58 [4].

Відповідно до положень зазначеного Планового порядку направлення пацієнтів, згідно з медичними показами, в заклади охорони здоров'я, що є учасниками пілотного проекту, та надання третинної (високоспеціалізованої) медичної допомоги у таких закладах, направлення пацієнтів до закладів охорони здоров'я, які надають третинну (високоспеціалізовану) медичну допомогу, здійснюється за наявності показань для госпіталізації (консультації) щодо надання третинної (висококваліфікованої) медичної допомоги у плановому порядку лікуючим лікарем відповідного профілю закладу охорони здоров'я державної або комунальної форм власності, що надає вторинну (спеціалізовану) медичну допомогу або третинну (високоспеціалізовану) медичну допомогу.

Щодо трактування визначення надання третинної (висококваліфікованої) медичної допомоги в екстрених випадках, то національний законодавець не дає чіткого переліку таких випадків, що, на нашу думку, становить прогалину в законодавстві. Доцільно було затвердити Наказом Міністерства охорони здоров'я Порядок надання третинної (висококваліфікованої) медичної допомоги у екстрених випадках.

Виходячи 3 тлумачення норми статті 35-3 Основ, ще однією із ознак третинної (висококваліфікованої) медичної допомоги є форми діяльності: консультації, проведення

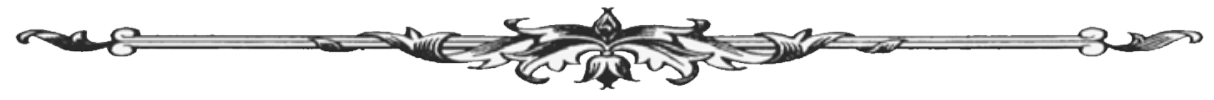


діагностики, лікування хвороб, травм, отруєнь, патологічних станів, ведення фізіологічних станів (під час вагітності та пологів).

На нашу думку, перелік зазначених форм є не повністю сформованим, оскільки увага законодавця не звернена на низку заходів щодо забезпечення підтримки та зміцнення здоров’я населення, профілактики захворювань, розвитку фізичних, морально-вольових та інтелектуальних здібностей людей.

Також варто виокремити такі ознаки третинної (висококваліфікованої) медичної допомоги, як застосування високотехнологічного обладнання та/або високоспеціалізованих медичних процедур високої складності, що слугує швидкому прийняттю рішення щодо діагнозу та надання якісних медичних послуг.

Висновки. Таким чином, норми актів національного законодавства у сфері охорони здоров'я, в тому числі й Основ законодавства України про охорону здоров'я, потребують удосконалення, зокрема норма ст. 35-3 Основ про визначення поняття третинної (висококваліфікованої) медичної допомоги. 3 урахуванням усіх основних ознак видається доцільним визначити третинну (висококваліфіковану) медичну допомогу як вид медичної допомоги, яка передбачає надання консультацій, проведення діагностики, лікування хвороб, травм, отруєнь, патологічних станів, ведення фізіологічних станів (під час вагітності та пологів), що надається в амбулаторних і стаціонарних умовах у плановому порядку або в екстрених випадках із застосуванням високотехнологічного обладнання, та/або високоспеціалізованих медичних процедур високої складності; направлення пацієнта, відповідно до медичних показань, для надання вторинної (спеціалізованої) медичної допомоги або третинної (високоспеціалізованої) медичної допомоги з іншої спеціалізації, з метою підтримки та зміцнення здоров'я населення, розвитку його фізичних, морально-вольових та інтелектуальних здібностей.

Також доцільно закріпити у законодавстві України, а саме у наказі Міністерства охорони здоров’я «Порядок надання третинної (висококваліфікованої) медичної допомоги у екстрених випадках», чіткий та вичерпний перелік екстрених випадків надання третинної (висококваліфікованої) медичної допомоги.

\section{Список використаних джерел:}

1. Основи законодавства України про охорону здоров’я: Закон України від 19 листопада 1992 року № 2801-XII. Відомості Верховної Ради Украӥни. 1993. № 4. Ст. 19.

2. Про затвердження переліків закладів охорони здоров'я, лікарських, провізорських посад, посад молодших спеціалістів з фармацевтичною освітою, посад професіоналів у галузі охорони здоров'я та посад фахівців у галузі охорони здоров'я з у закладах охорони здоров'я: Наказ Міністерства охорони здоров’я України від 28 жовтня 2002 року № 385. Офіичійний вісник Украӥни. 2002. № 46. Ст. 2116.

3. Порядок організації медичного обслуговування та направлення пацієнтів до закладів охорони здоров'я, що надають вторинну (спеціалізовану) та третинну (високоспеціалізовану) медичну допомогу: Наказ Міністерства охорони здоров'я України від 05 жовтня 2011 року № 646. Офіиійний вісник України. 2011. № 99. Ст. 364.

4. Про затвердження нормативно-правових актів МОЗ України та НАМН України щодо реалізації постанови Кабінету Міністрів України від 14 червня 2017 року № 425 «Деякі питання реалізації пілотного проекту щодо зміни механізму фінансування надання медичної допомоги в окремих науково-дослідних установах Національної академії медичних наук»: Наказ Міністерства охорони здоров'я України, Національної академії медичних наук України від 28 червня 2017 року № 967/58. Офіиійний вісник Украӥни. 2017. № 80. Ст. 2483.

5. Про Стратегію сталого розвитку «Україна - 2020»: Указ Президента України від 12 січня 2015 року. Офіційний вісник України. 2015. № 4. Ст. 67.

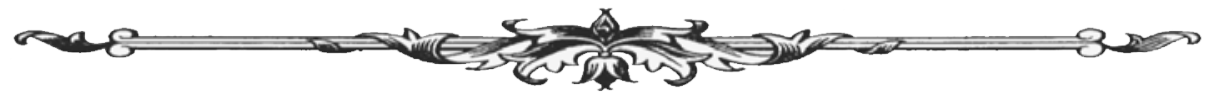

